\title{
Mass transport in the Bay of Biscay from an inverse box model
}

\author{
Eugenio Fraile-Nuez, ${ }^{1}$ Francisco Plaza, ${ }^{2}$ Alonso Hernández-Guerra, ${ }^{3}$ \\ Manuel Vargas-Yáñez, ${ }^{4}$ and Alicia Lavín ${ }^{5}$ \\ Received 7 August 2007; revised 13 February 2008; accepted 27 March 2008; published 24 June 2008.
}

[1] Mass transports in the Bay of Biscay for thermocline, intermediate and deep water masses are estimated from a box inverse model applied to hydrographic data from a quasi-synoptic survey carried out in August 2005. The model obeys conservation statements for mass in a volume of ocean bounded by 43 full depth CTD stations in the horizontal, and neutral density layers in the vertical. It permits advective exchange between layers and an adjustment of the Ekman transport and the freshwater flux divergences. Bay of Biscay has a thermocline transport of $-8.0 \pm 0.7 \mathrm{~Sv}$ with an anticyclonic recirculation of $+6.9 \pm 0.6 \mathrm{~Sv}$. An equatorward flow of $+0.5 \pm 0.4 \mathrm{~Sv}$ is attributed to the slope current close to the northwestern Spanish coast. The mean wind stress curl for the region corresponds with a clockwise upper layer flow which produces a downwelling of $-0.6 \pm 0.4 \mathrm{~Sv}$. The surface circulation pattern agrees with the obtained with the Jason-1 altimeter. Intermediate waters follow the same surface pattern of the thermocline waters as a subsurface eastern boundary current with an eastward flow of $-7.9 \pm 1.0 \mathrm{~Sv}$ and a southwestward flow of $+8.0 \pm 1.0 \mathrm{~Sv}$. Finally, our results show that deep waters also flow into the box with a net transport of $-3.6 \pm 2.0 \mathrm{~Sv}$ and flow out of the box with a net transport of $2.3 \pm 2.0 \mathrm{~Sv}$.

Citation: Fraile-Nuez, E., F. Plaza, A. Hernández-Guerra, M. Vargas-Yáñez, and A. Lavín (2008), Mass transport in the Bay of Biscay from an inverse box model, J. Geophys. Res., 113, C06023, doi:10.1029/2007JC004490.

\section{Introduction}

[2] The area studied in this work is located in the midlatitudes of the northeastern Atlantic, off western Europe. It is defined as the area between $43^{\circ} \mathrm{N}$ and $49^{\circ} \mathrm{N}$, $01^{\circ} \mathrm{W}$ and $12^{\circ} \mathrm{W}$ in the Bay of Biscay (Figure 1). The release of heat from the ocean to the atmosphere in wintertime is largely responsible for the mild winters of Northwest Europe and the path of the North Atlantic Current is vital to European climate. Information on the surface circulation over the Biscay Abyssal Plain, either wind-driven or geostrophic, is relatively scarce [van Aken, 2002]. Pingree [1993] has shown with Lagrangian drifter studies the North Atlantic Central Water (NACW), supplied by the North Atlantic Current penetrates southeastward into the Bay of Biscay, a feature later confirmed by Chantry [1995], who depicted anticyclonic circulation over the Bay

\footnotetext{
${ }^{1}$ Instituto Español de Oceanografía, Centro Oceanográfico de Canarias, Santa Cruz de Tenerife, Spain.

${ }^{2}$ Instituto Español de Oceanografía, Centro Oceanográfico de Murcia, San Pedro del Pinatar, Spain.

${ }^{3}$ Facultad de Ciencias del Mar, Universidad de Las Palmas de Gran Canaria, Las Palmas, Spain.

${ }^{4}$ Instituto Español de Oceanografía, Centro Oceanográfico de Málaga, Fuengirola, Spain.

${ }^{5}$ Instituto Español de Oceanografía, Centro Oceanográfico de Santander, Santander, Spain.

Copyright 2008 by the American Geophysical Union. 0148-0227/08/2007JC004490
}

of Biscay plain. The wind stress curl for the region is relatively prominent, and is a possible candidate for the clockwise upper layer flow in the Bay of Biscay [Isemer and Hasse, 1987]. This anticyclonic circulation produces a mean subduction rate of 0.5 Sv [Paillet and Mercier, 1997].

[3] Wind-driven flow (Sverdrup circulation) induces the subpolar and subtropical gyres in the North Atlantic. The Bay of Biscay is located in the eastern part of these gyres, influenced by the North Atlantic drift to the north and the Azores Current to the south. The currents induced by this general circulation are not very intense in the Bay of Biscay. The general oceanic (central area) circulation of Bay of Biscay is characterized by weak anticyclonic circulation, as show by Koutsikopoulos and Le Cann [1996], with cyclonic on the continental margin [Pingree, 1993]. These weak currents are generally variable and the main feature of the oceanic area is the frequent presence of cyclonic and anticyclonic eddies which are the result of the continental margin currents instabilities interacting with the bottom topography. Some of these eddies $(100 \mathrm{~km}$ diameter, $500 \mathrm{~m}$ thickness and centered at $200 \mathrm{~m}$ depth) can persist for up to 1 year [Pingree and Le Cann, 1992].

[4] Frouin et al. [1990] and Haynes and Barton [1990] introduced the Iberian Poleward Current (IPC), a poleward jet that develops in fall and winter over the Iberian and Cantabrian upper slopes and advects warm and salty waters into the Bay of Biscay. IPC is a robust feature of the winter circulation along the Iberian Peninsula, but that the eastward penetration of the jet along the Cantabrian Slope and of the associated warm water tongue in the Bay of Biscay is 


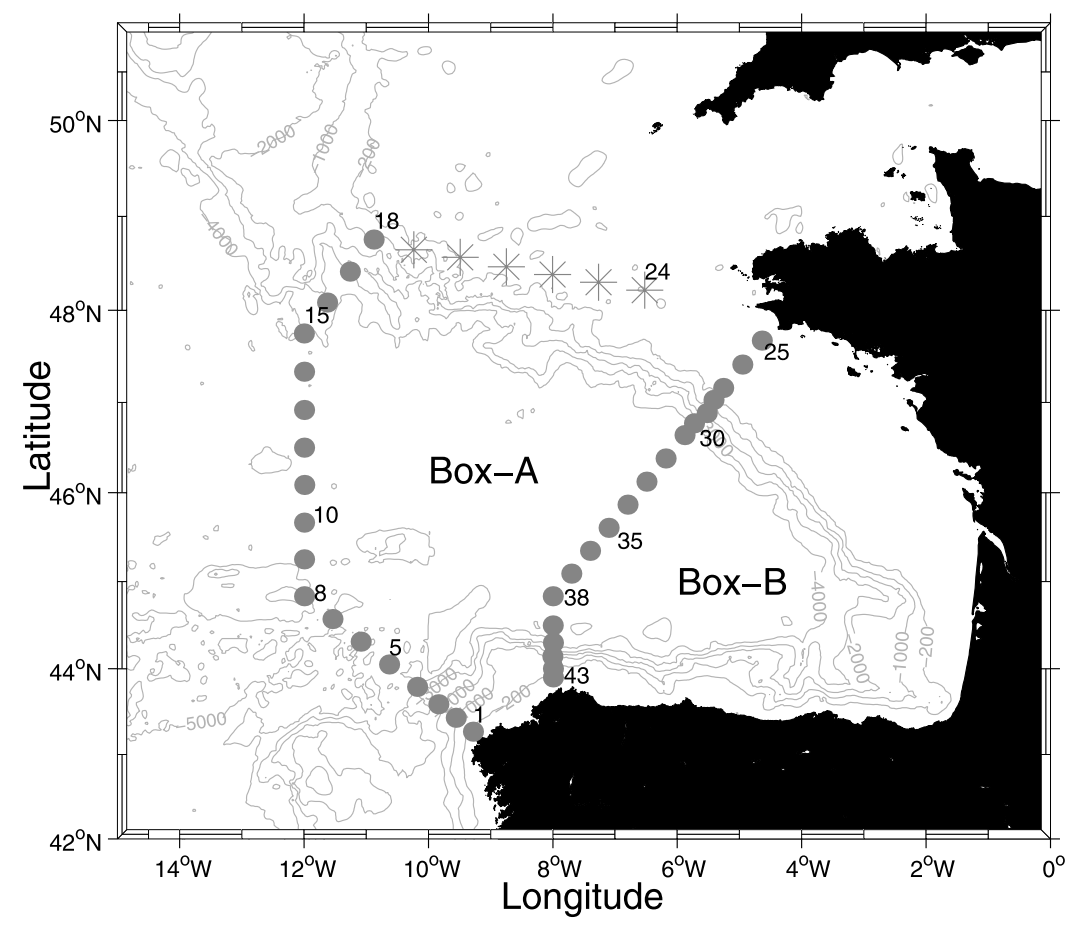

Figure 1. Locations of the CTD stations in the Bay of Biscay. Solid dots were used for Box A and Box B. Stars represent the north transect of Box A, carried out in VACLAN0706 cruise. For reference, the 200-m, 1000-m, 2000-m, 3000-m, 4000-m, and 5000-m isobaths are shown [Smith and Sandwell, 1997].

subject to interannual variability [Friocourt et al., 2007]. The fate of the IPC in summer time is still unclear; Haynes and Barton [1990] report the complete disappearance of the poleward flow in the upper layers off the western Iberian Peninsula, but Peliz et al. [2002] and this study suggest a possible persistence of the IPC in summer, though much weakened and shifted offshore.

[5] The main purpose of our study is to determine the mass transport in the Bay of Biscay and discuss it in terms of water masses. Mass transport is estimated using an inverse method that provides a solution within dynamically consistent error bars. After a brief presentation of the collected hydrographic data in section 2 we will describe the different water masses using $\theta / S$ diagrams in section 3 . In section 4 the inverse box model is described and finally our results and discussion are given in section 5 .

\section{Data}

[6] The VACLAN0805 (CLimatic VAriability of the oceanic waters in the North Atlantic ocean) cruise occurred over two legs aboard the R/V Thalassa. The first leg was carried out between 19 and 29 August 2005 and the second one between 30 August and 11 September 2005. We selected 43 Seabird 911+ CTD stations from the surface to the bottom in order to complete two boxes in the Bay of Biscay (Figure 1). Box A consisted of 43 CTD stations taken along three different sections. A western transect (station 1 to 18); an eastern transect (station 25 to 43); and finally, owing to several technical problems occurring during the VACLAN0805 cruise, a northern transect was carried out one year later but in the same season during VACLAN0706 cruise (stations 19 to 24, in order to close the box). Box B is the space between the eastern transect of Box A (stations 25 to 43 ) and the coast.

[7] The CTD sensors were calibrated at the SeaBird laboratory before the cruise. Water samples were collected at each station with a twenty-four 10-L-bottle carousel. Onboard salinity calibration was carried out with a Guildline Autosal 8400B salinometer with a precision better than 0.002 for single samples. In situ precision comparisons using 6 samples, 2 at $4820-\mathrm{m}$ depth from different bottles (station 9) and 4 at 4000-m depth (station 7) from the same bottle were 0.003 and 0.002 , respectively.

[8] Geostrophic velocity anomaly gridded data $\left(1 / 3^{\circ} \times\right.$ $1 / 3^{\circ}$ on a Mercator grid) based on four satellites (TOPEX/ POSEIDON, Jason-1+ ERS, Envisat) were used to determine the surface circulation pattern (Jason-1, 2006, http://www. aviso.oceanobs.com/fr/accueil/index.html). These data were obtained for the same period as the VACLAN0805 cruise.

[9] Two climatological data sets were used in order to obtain two different products: temperature and salinity values to compute the horizontal area at a given neutral surface density for Box A [Levitus and Boyer, 1994] and wind stress fields to compute the Ekman transport for each transect of Box A [da Silva et al., 1994].

[10] Freshwater flux was estimated as [(E-P) + R], where (E-P) is the climatology evaporation and precipitation rate from the DASILVA SMD94 database of da Silva et al. [1994] and R is the contribution of two rivers (Loire and Garonne) [Koutsikopoulos and Le Cann, 1996].

\section{Water Masses}

[11] Potential temperature/salinity $(\theta / S)$ diagrams (Figure 2) and vertical sections of potential temperature, 


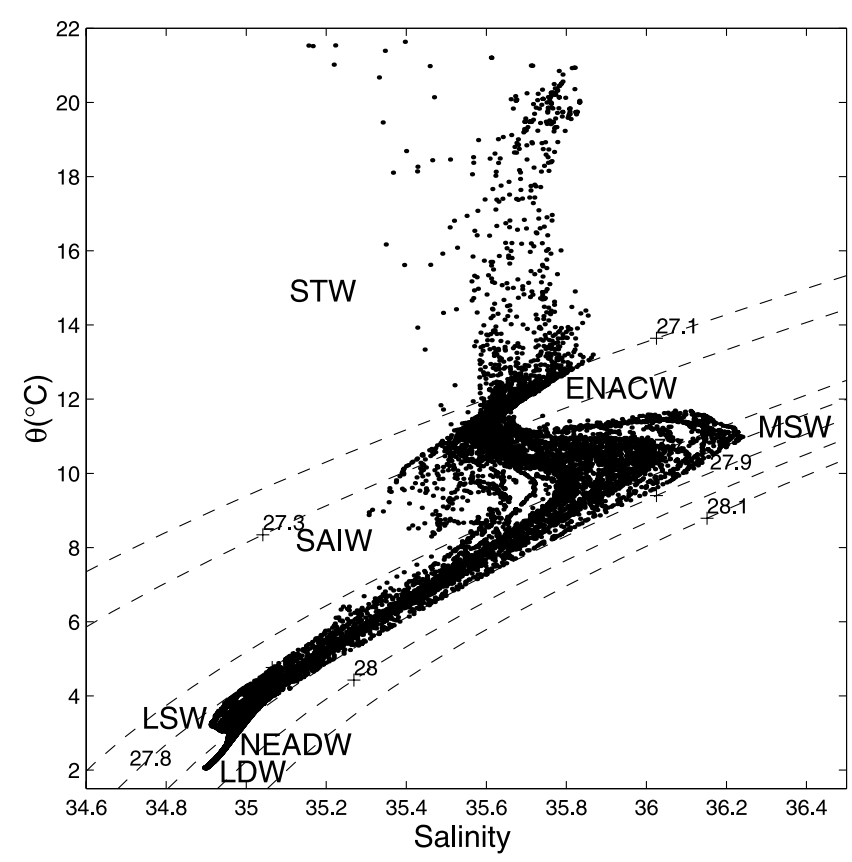

Figure 2. Potential temperature-salinity diagram of the VACLAN0905 stations. Approximate positions of the water types discussed in this paper are indicated as: STW, Surface Thermocline Water; ENACW, Eastern North-Atlantic Central Water; MSW, Mediterranean Sea Water; SAIW, Sub-Arctic Intermediate Water; LSW, Labrador Sea Water; NEADW, North-East Atlantic Deep Water; and LDW, Labrador Deep Water.

salinity and neutral densities $\left(\gamma_{n}\right)$ illustrate the presence of various water masses and their associated spatial and density/depth distributions (Figures 3-5) for the Bay of Biscay. In Figure 2 we present $\theta / S$ diagram, on which we have included several selected constant potential density (isopycnal) contours $\left(\sigma_{\theta}\right)$. Note that Figure 2 is the only one in this paper where we refer to potential density (at surface pressure), while neutral density $\left(\gamma_{n}\right)$ is used everywhere else in this paper. The reason for this is that potential density is a direct function of $\theta$ and $S$, so it is a straightforward quantity to plot in $\theta / S$ diagram, while neutral density is also a function of depth [Jackett and McDougall, 1997].

[12] Thermocline waters are located between the surface and the isopycnal of $\sigma_{\theta}=27.3 \mathrm{~kg} \mathrm{~m}^{-3}$ (approximately $600 \mathrm{~m})$. At this level, $\theta / S$ curves have an inverse " $\mathrm{S}$ " shape with a salinity minimum (Figure 2). This subsurface salinity minimum prohibits direct interaction and mixing with water masses above [Pollard and Pu, 1985; van Aken, 2000b; González-Pola et al., 2005]. Just above this minimum is the permanent thermocline, followed by a narrow band of data points with the $\theta / S$ characteristics of Eastern North-Atlantic Central Water (ENACW), approximately between the isopycnals of 27.1 and $27.3 \mathrm{~kg} \mathrm{~m}^{-3}$.

[13] Seasonal thermocline waters (STW) are located between isopycnals 26.4 and $27.1 \mathrm{~kg} \mathrm{~m}^{-3}$ (approximately $150 \mathrm{~m}$ ). Both temperature and salinity increase upward to the bottom of the seasonal thermocline, where a salinity maximum is observed. Huthnance et al. [2002] observed an interannual variation in ENACW salinity near the northwest Iberian margin and a relatively large-scale variability near
Porcupine Bank (latitude $51^{\circ} \mathrm{N}-53^{\circ} \mathrm{N}$ and longitude $12^{\circ} \mathrm{W}-14^{\circ} \mathrm{W}$ ) due to the influence of the cyclonic subarctic gyre. These authors suggest that the interannual variability may be due to either atmospheric forcing in winter or advection of Central Water from further west. On the other hand, the ENACW suffers a salinification due to winter cooling of saline surface water near the European ocean margin, west and northwest of the Spanish and Portuguese coasts [Pollard and Pu, 1985]. Subsequently, a cool, saline Mode Water formed by winter convection subducts southward into the permanent thermocline [van Aken, 2001]. A cloud of wide-ranging data points from above the thermocline reflects the effects of seasonal stratification and the interaction with fresher water near the shelf edge [van Aken, 2001]. In the coastal domain of the Bay of Biscay, shallower waters $(<150 \mathrm{~m})$ are affected by the freshwater; consequently, the interannual, seasonal and mesoscale variability in salinity patterns is affected by the river runoff. The Loire and Garrone rivers reduce surface salinity locally on the French continental shelf [Puillat et al., 2004]. Low-salinity waters from the Adour and Garonne estuaries may cover a great part of the eastern Cantabrian shelf in winter and spring time [Vincent and Kurc, 1969; Vincent, 1973; Botas et al., 1989; Koutsikopoulos and Le Cann, 1996].

[14] The intermediate waters, located in the density range $\sigma_{\theta} 27.3-27.9 \mathrm{~kg} \mathrm{~m}^{-3}$, are Sub-Arctic Intermediate Water (SAIW), Mediterranean Sea Water (MSW) and Labrador Sea Water (LSW). The density ranges for these water masses show considerable overlap, which allows both diapycnal and isopycnal mixing [van Aken, 2000b]. The presence of the continental shelf edge enhances the diapycnal mixing [Garrett, 1991] and forces the circulation to be aligned with the topography as a subsurface eastern boundary current at intermediate levels [Swallow et al., 1977; Ambar and Howe, 1979; Reid, 1994; Paillet and Mercier, 1997; Mazé et al., 1997]. The SAIW is a cold and fresh water mass that originates from the northwestern Atlantic. One branch of the SAIW subducts and recirculates in the northern cyclonic gyre, while the remainder subducts below the North Atlantic Current and flows toward the eastern Atlantic margin [Arhan, 1990]. It is characterized by an intermediate salinity minimum between $\sigma_{\theta} 27.3-27.9 \mathrm{~kg} \mathrm{~m}^{-3}$. The MSW is known to originate from the Mediterranean Sea and circulates through the Strait of Gibraltar as an outflow. A branch of the MSW spreads from Cape St. Vincent northward to at least as far as Porcupine Bank at $53^{\circ} \mathrm{N}$ and is characterized by a salinity maximum $\left(\mathrm{S} \approx 36-36.2\right.$ and $\left.\sigma_{\theta} \approx 27.7 \mathrm{~kg} \mathrm{~m}^{-3}\right)$ in the Bay of Biscay [van Aken and Becker, 1996; van Aken, 2000b]. The formation of LSW takes place in the Labrador Sea and is characterized by a relatively deep salinity minimum centered at $\sigma_{\theta}=27.8$ in the $\theta / S$ diagram, overlying the deeper levels where North-East Atlantic Deep Water (NEADW) and Labrador Deep Water (LDW) are also observed. The abyssal water mass, LDW, is characterized by a low and near-bottom salinity minimum whilst NEADW is characterized by a deep salinity maximum overlaying the LDW salinity minimum [van Aken, 2000a].

\section{Inverse Box Model}

[15] An inverse box model has been applied to Box A in order to obtain the geostrophic flow that obeys conservation 

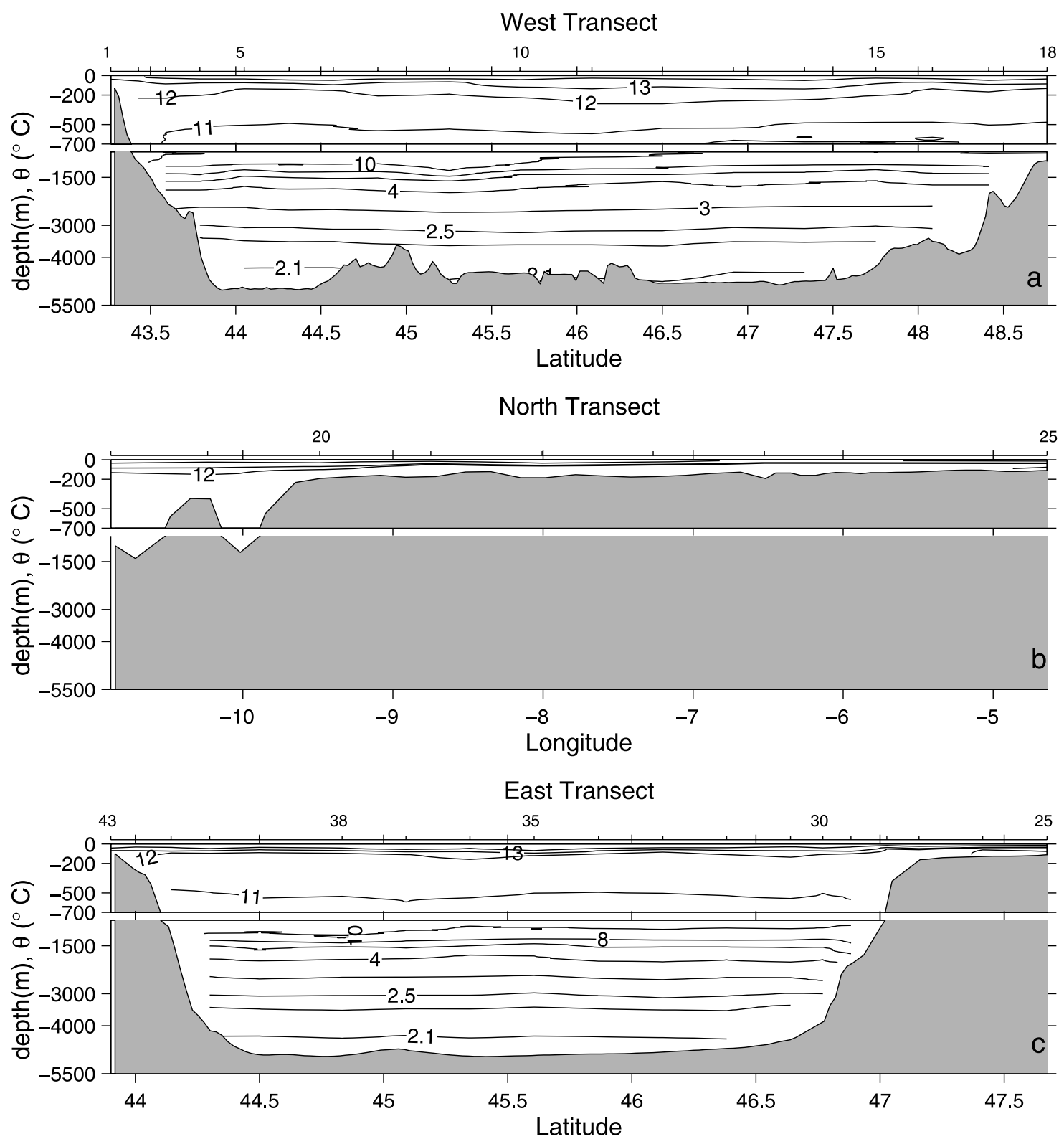

Figure 3. Potential temperature $\left({ }^{\circ} \mathrm{C}\right)$ for the (a) west, (b) north, and (c) east sections. Note that the vertical scale changes at $700 \mathrm{~m}$ depth. CTD numbering is indicated in the top axis.

statements for different properties in a volume of ocean bounded by hydrographic sections and land in the horizontal and neutral density layers in the vertical. It assumes that the ocean is hydrostatic and in geostrophic balance, but permits exchange of properties between adjacent layers [Wunsch, 1977, 1978; Hernández-Guerra et al., 2005; Machín et al., 2006]. The inverse box model provides an estimate of the velocities at the reference level, dianeutral velocities and freshwater flux along with their error covariance.

[16] The reference level of no motion used to integrate the thermal wind equation was $28.072 \mathrm{~kg} \mathrm{~m}^{-3}$ neutral density (roughly $3000 \mathrm{~m}$ ), following the study of Ganachaud [2003a] for the North Atlantic. If one or both stations of each station pair is shallower than this level, the deepest common level was used as the velocity reference. We have divided up the water column into 12 layers of neutral density (Table 1), which are roughly defined as water mass boundaries. The upper three layers coincide with the thermocline waters (from surface to $27.38 \mathrm{~kg} \mathrm{~m}^{-3}$ ), the next three (from 27.38 to $27.922 \mathrm{~kg} \mathrm{~m}^{-3}$ ) with intermediate waters, and the lowest layers (from 27.922 to the bottom) with NEADW and LDW.

[17] Ekman transport has been computed across every section from climatological wind stress fields which is added to the shallowest layer. Climatological Ekman transport for the western, northern and eastern sections is -0.11 , 0.26 and $0.45 \mathrm{~Sv}$, respectively. The inverse model adjusts these values to the specific oceanographic conditions at the time of our survey.

[18] A freshwater flux is added to the shallowest layer of Box $\mathrm{B}$ as $\left[(E-P)+\left(R_{l}+R_{g}\right)\right]$. Fw $=\left[\left(-3 \times 10^{-4}\right)+\right.$ $(-0.03)+(-0.04)]=-0.07 \mathrm{~Sv}\left(1 \mathrm{~Sv}=10^{6} \mathrm{~m}^{3} \mathrm{~s}^{-1} \approx\right.$ $\left.10^{9} \mathrm{~kg} \mathrm{~s}^{-1}\right)$; the negative sign means that the net transport flows into the box. 

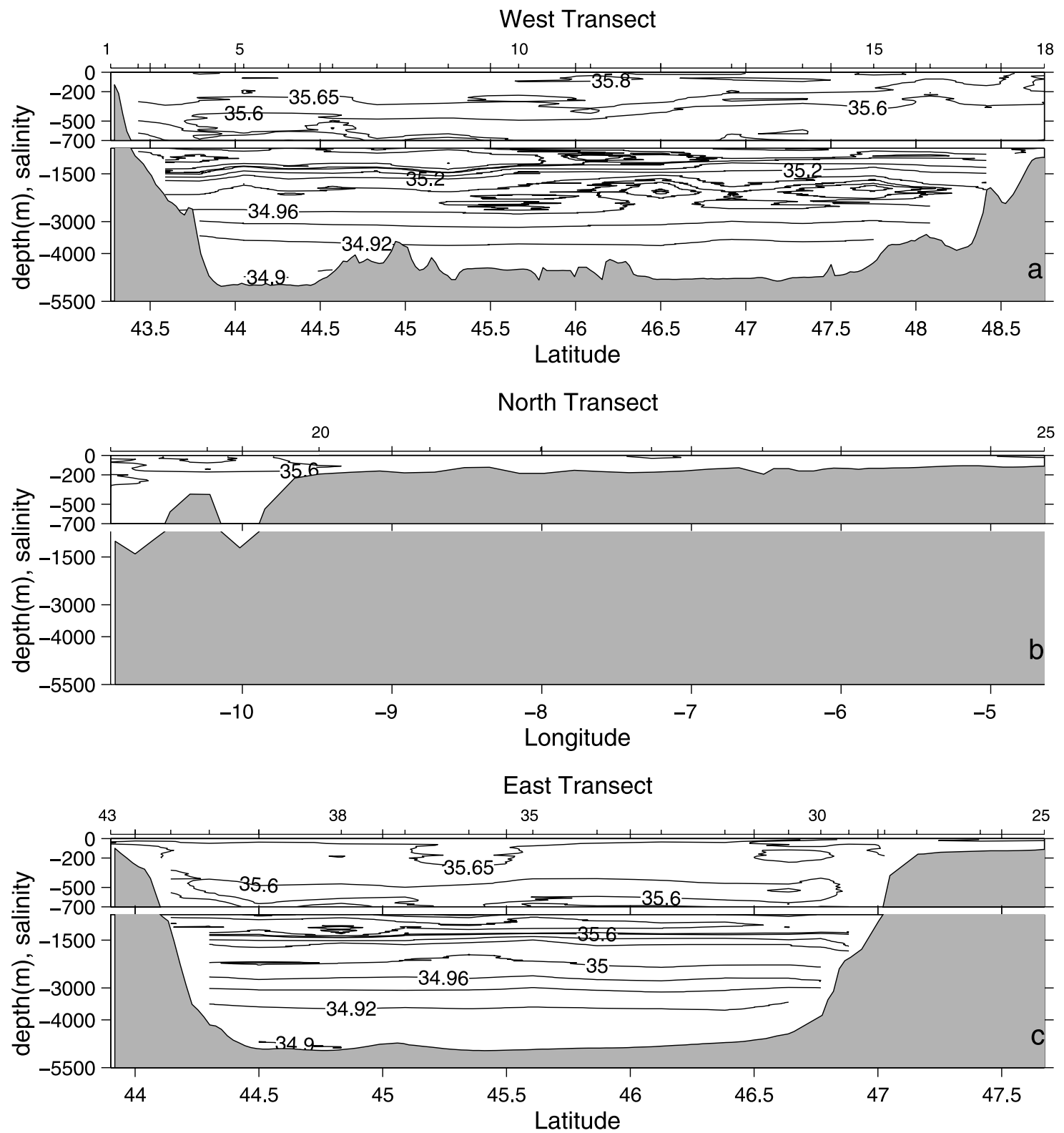

Figure 4. Salinity sections. See Figure 3 caption for details.

[19] In this model we have considered conservation of mass, vertical transfer, Ekman and freshwater fluxes. There are represented in the following equation:

$$
\iint_{A_{x}} \rho\left(v_{r}+b\right) d x d z+A_{z}(-\bar{w} \bar{\rho})+F_{w}+T_{E k}=0,
$$

where $A_{x}$ represents the vertical areas of all enclosing boundaries, $\rho$ is the density field, $v_{r}$ are the velocities relative to a reference level, $b$ are the reference level velocities, $x$ and $z$ are the horizontal and vertical coordinates, respectively, $A_{z}$ are the horizontal area of given neutral surfaces bounded by the hydrographic sections and the coast, $w$ are the dianeutral velocities and $F_{w}$ is the freshwater mass input incorporated to the layer in contact with the atmosphere, and finally $T_{E k}$ is the sum of two terms $\left(T_{E k_{\text {climatology }}}\right.$ and $\left.\Delta T_{E k}\right)$. The first one is calculated from the
Dasilva SMD94 Climatology average wind stress field for summer [da Silva et al., 1994], while the latter is a result of the model. $T_{E k}$ is also incorporated to the layer in contact with the atmosphere.

[20] The inverse box model matrix is written as

$$
E x+n=-y,
$$

where $E$ is a matrix, with elements equal to the product of the area, density, and mass for each station pair and layer, $n$ is a column vector whose elements are the error of each equation, $x$ is the column vector containing the unknown of the system,

$$
\left(\begin{array}{c}
\left(b_{i}\right)_{i=1, \ldots, N} \\
\left(w_{k}\right)_{k=1, \ldots, M-1} \\
\Delta T_{E k} \\
F_{w}
\end{array}\right),
$$



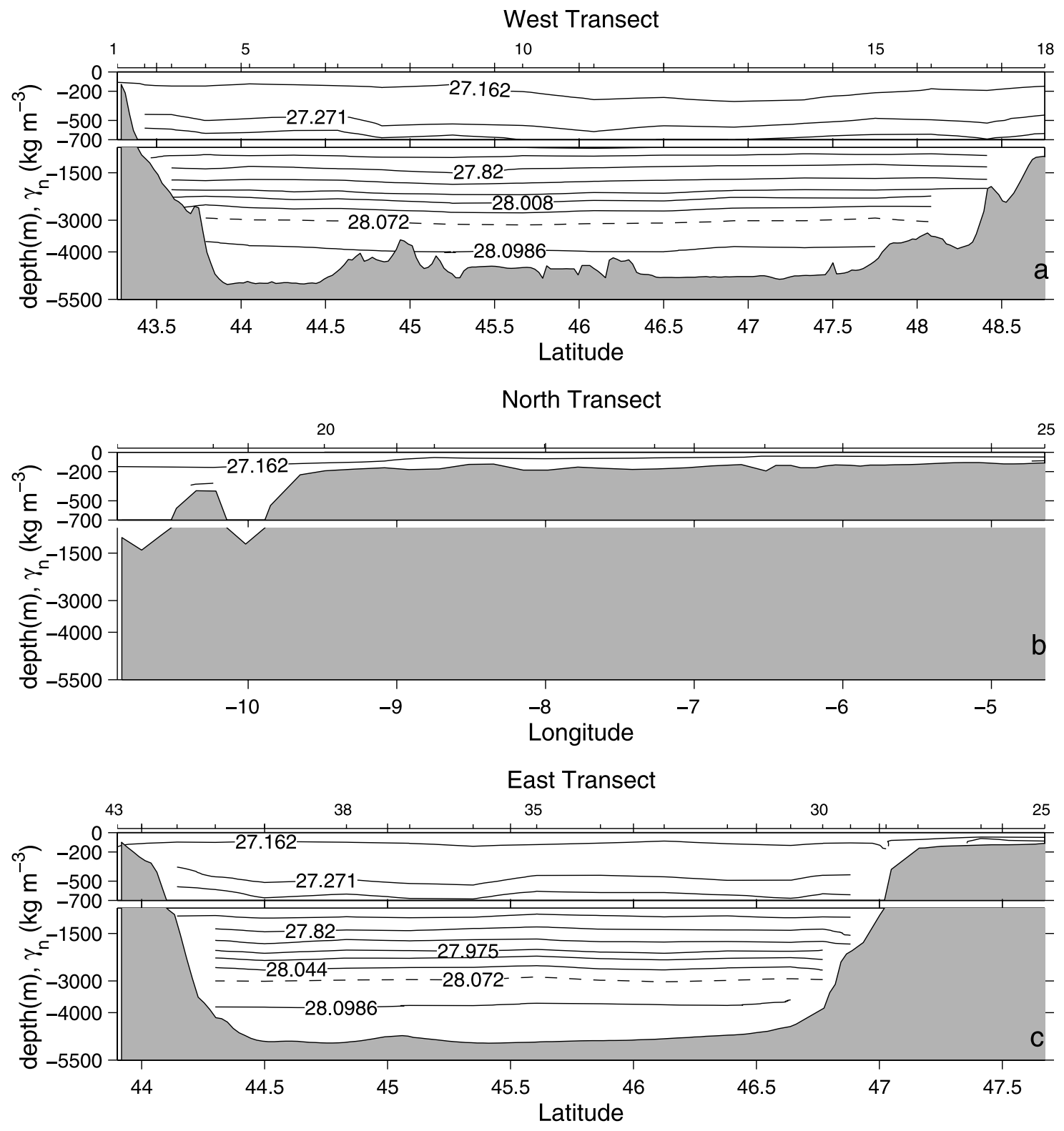

Figure 5. Neutral density sections. See Figure 3 caption for details.

where $N$ is the number of station pairs, $M$ is the number of layers, $\Delta T_{E k}$ is the adjustment of the Ekman transport and $F_{w}$ is the freshwater flux that are solved as part of the inversion [Ganachaud, 1999, 2003b]. Finally, $y$ is a vector with elements equal to the property imbalance resulting from the relative velocity.

[21] In this model we introduced the dianeutral fluxes in order to consider the mixing across isoneutral layers. These terms have to be evaluated with information from the box boundaries, which prevents studying their horizontal spatial variability within the box [Ganachaud, 2003b; Machin, 2004; Fraile-Nuez, 2005].

[22] Matrix $E$ in equation (2) consists of 26 equations for mass conservation (12 individual layers of Box A, 1 top-tobottom, Box A, 12 individual layers, Box B, 1 top-tobottom, Box B). The vector $x$ in equation (2) is formed by 57 unknowns, 42 reference-level velocities, 11 dianeutral velocities, 3 Ekman transport adjustments and 1 freshwater
Table 1. Layer Definitions and Approximate Equivalences With Depth and Water Masses Used in the Inversion Model

\begin{tabular}{lccc}
\hline Layer & $\gamma_{n}$ & Depth $(\mathrm{m})$ & Water Mass \\
\hline 1 & surface to 27.162 & surface to 150 & STW \\
2 & $27.162-27.271$ & $150-480$ & ENACW \\
3 & $27.271-27.38$ & $480-630$ & ENACW \\
4 & $27.38-27.62$ & $630-960$ & SAIW,MSW,LSW \\
5 & $27.62-27.82$ & $960-1370$ & SAIW,MSW,LSW \\
6 & $27.82-27.922$ & $1370-1740$ & SAIW,MSW,LSW \\
7 & $27.922-27.975$ & $1740-2060$ & NEADW \\
8 & $27.975-28.008$ & $2060-2300$ & NEADW \\
9 & $28.008-28.044$ & $2300-2620$ & NEADW \\
10 & $28.044-28.072$ & $2620-3000$ & NEADW \\
11 & $28.072-28.0986$ & $3000-3830$ & LDW \\
12 & 28.0986 to bottom & 3830 to bottom & LDW \\
\hline
\end{tabular}


Table 2. Cases Considered in the Sensitivity Analysis

\begin{tabular}{cccccc}
\hline & \multicolumn{2}{c}{ Deep Ocean } & & \multicolumn{2}{c}{ Shallow Ocean } \\
\cline { 2 - 3 } \cline { 5 - 6 } Case & $\begin{array}{c}\text { Reference } \\
\text { Level }\left(\gamma_{n}\right)\end{array}$ & $R_{b b}\left(\mathrm{~m}^{2} \mathrm{~s}^{-2}\right)$ & & $\begin{array}{l}\text { Reference } \\
\text { Level }\left(\gamma_{n}\right)\end{array}$ & $R_{b b}\left(\mathrm{~m}^{2} \mathrm{~s}^{-2}\right)$ \\
\hline 1 & 27.38 & 0.01 & & $27.38 /$ bottom & 0.03 \\
2 & 27.38 & 0.02 & & $27.38 /$ bottom & 0.05 \\
3 & 27.38 & 0.03 & & $27.38 /$ bottom & 0.07 \\
4 & 28.072 & 0.01 & & bottom & 0.03 \\
5 & 28.072 & 0.02 & & bottom & 0.05 \\
6 & 28.072 & 0.03 & & bottom & 0.07 \\
7 & bottom & 0.01 & & bottom & 0.03 \\
8 & bottom & 0.02 & & bottom & 0.05 \\
9 & bottom & 0.03 & & bottom & 0.07 \\
\hline
\end{tabular}

flux. These 57 unknowns were solved with the 27 initial equations and a preliminary variance for each velocity and for each constraint using the Gauss-Markov method [Wunsch, 1996]. For the a priori velocity variance we have considered the same value for all station pairs over the open ocean and a higher value over the shallow waters close to the Spanish and French coasts. They were $\left(0.02 \mathrm{~m} \mathrm{~s}^{-1}\right)^{2}$ and $\left(0.05 \mathrm{~m} \mathrm{~s}^{-1}\right)^{2}$, respectively. We assigned higher values to the a priori variance for each constraint in the thermocline than in the deepest layer, as by Joyce et al. [2001]; $(0.6 \mathrm{~Sv})^{2}$ for the first three layers, $(0.4 \mathrm{~Sv})^{2}$ for the next three layers and $(0.2 \mathrm{~Sv})^{2}$ for the last six layers. The a priori variance for the average dianeutral velocity was $\left(10^{-6} \mathrm{~m} \mathrm{~s}^{-1}\right)^{2}$. The Ekman transport and freshwater flux uncertainty were assigned to be $50 \%$ of the climatological mean values. All the uncertainties used in this paper are the suggested by Ganachaud [2003a] for the North Atlantic Ocean. According to Gauss-Markov estimator, the error bars of the mass transports per layers only depend on the a priori variances of the solutions and the error of each equation, as well as the density and the area of the section. A study of the solution using different a priori variances have been carried out in section 4. Therefore, same results are expected if neither the area of the section nor the a priori variances change significantly.

[23] In order to explore the sensitivity of the solution to changes both in the reference level and the a priori uncertainties in reference-level velocities, a sensitivity test has been carried out. The inverse box model has been run for three different reference levels $\left(27.38 \mathrm{~kg} \mathrm{~m}^{-3}\right.$, located between the surface and the intermediate layers; $28.072 \mathrm{~kg} \mathrm{~m}^{-3}$, roundly at $3000 \mathrm{~m}$, following the study of Ganachaud [2003a] for the North Atlantic; and the bottom) and for three different ranges of uncertainties in the reference-level velocities, $R_{b b},\left(0.01 \mathrm{~m} \mathrm{~s}^{-1}\right)^{2}$, $\left(0.02 \mathrm{~m} \mathrm{~s}^{-1}\right)^{2}$ and $\left(0.03 \mathrm{~m} \mathrm{~s}^{-1}\right)^{2}$ for the open ocean station pairs and $\left(0.03 \mathrm{~m} \mathrm{~s}^{-1}\right)^{2},\left(0.05 \mathrm{~m} \mathrm{~s}^{-1}\right)^{2}$ and $\left(0.07 \mathrm{~m} \mathrm{~s}^{-1}\right)^{2}$ over the shallow waters. Table 2 shows the nine cases. The results indicate that the model behavior is fairly independent of changes in these parameters. The inverse model satisfies the imposed constraints despite changes in the reference level or the a priori uncertainties. The final velocity fields do not differ greatly among the nine cases; however, case 5, produces the most consistent pattern, as compared with the previous knowledge of the region and the in situ surface geostrophic velocity calculated with the satellite altimeter.

[24] In order to quantify the new information that the different boxes adds to the model, another sensitivity analysis consisted of applying the inverse box model to each separate box (A, B). Using the individual boxes also reduces the number of equations and simplifies the system of equations. The results found this way are consistent with the joint solution.

[25] Another important consideration was to test the synopticity of the northern section of Box A, as this section was occupied one year after than the others. Since the northern section is very shallow, water depth less than $200 \mathrm{~m}$, (see Figures 3b, 4b, and 5b), the net transport for the northern section is not statistically significant. In previous studies, Hernández-Guerra et al. [2005] and Machín et al. [2006] have considered the isobath of $200 \mathrm{~m}$ as a coast line and, therefore, the presence or absence of this section should not produce a significant change in the net transport of the model.

\section{Results}

[26] The inverse box model calculates the velocities with error bars for the reference layer as a function of each station pair (Figure 6a). Velocity values of $b_{i}$ for the deeper station pairs are uniformly very low $\left(<2 \mathrm{~cm} \mathrm{~s}^{-1}\right)$, higher values are found over the shallow Spanish, Irish and French continental shelf $\left(2<b_{i}<12 \mathrm{~cm} \mathrm{~s}^{-1}\right)$ [Puillat et al., 2004]. The uncertainties of each $b_{i}$ used in this model were the a priori values as in other inverse solutions [Ganachaud et al., 2000; Joyce et al., 2001; Hernández-Guerra et al., 2005].

[27] Figure $6 \mathrm{~b}$ shows the dianeutral velocities between layers determined by our inverse box model together with the error bars. Negative values are found every layer, although only the first and the third are statistically significant. Downwelling of the thermocline waters, $-0.6 \pm$ $0.4 \mathrm{~Sv}$, corresponds to a negative Ekman pumping in the subtropical gyres and agrees with that reported by Paillet and Mercier [1997] for the same area. This result is also in agreement with the mean wind stress curl for the region which produces a clockwise upper layer flow in the Bay of Biscay [Isemer and Hasse, 1987; Pingree, 1993].

[28] The results from the inverse calculations were used to compute the new integrated mass transport per density layer (Figure 6c). Figure 7 shows the mass transports for groups of station pairs with their standard deviation in Sverdrups. The western transect of Box A is divided into three groups from the north to the south; the first, from stations 18 to 9 , is the NACW branch that flows eastward to the Bay of Biscay with a net transport of $-8.0 \pm 0.7 \mathrm{~Sv}$. The second, from stations 9 to 2 , is the anticyclonic recirculation of the NACW flowing southwestward with a net transport of $+6.9 \pm 0.6 \mathrm{~Sv}$. The last group, close to the Spanish coast, from stations 2 to 1 , is associated with the IPC. The annual cycle of the IPC is attributed to the seasonal distribution of the wind off the Iberian Peninsula. Our results show an equatorward flow of $+0.5 \pm 0.4 \mathrm{~Sv}$ for summertime, when the cruise was carried out, but in wintertime the weakening of the southward component of the wind stress leads to a development of the thermohaline poleward slope current [Durrieu de Madron et al., 1999]. Friocourt et al. [2007] have obtained over the western Iberian shelf a summer equatorward circulation of the IPC with velocities up to $8 \mathrm{~cm} \mathrm{~s}^{-1}$ along the northern Portuguese coast. Our result agrees with those obtained by these authors for the same 

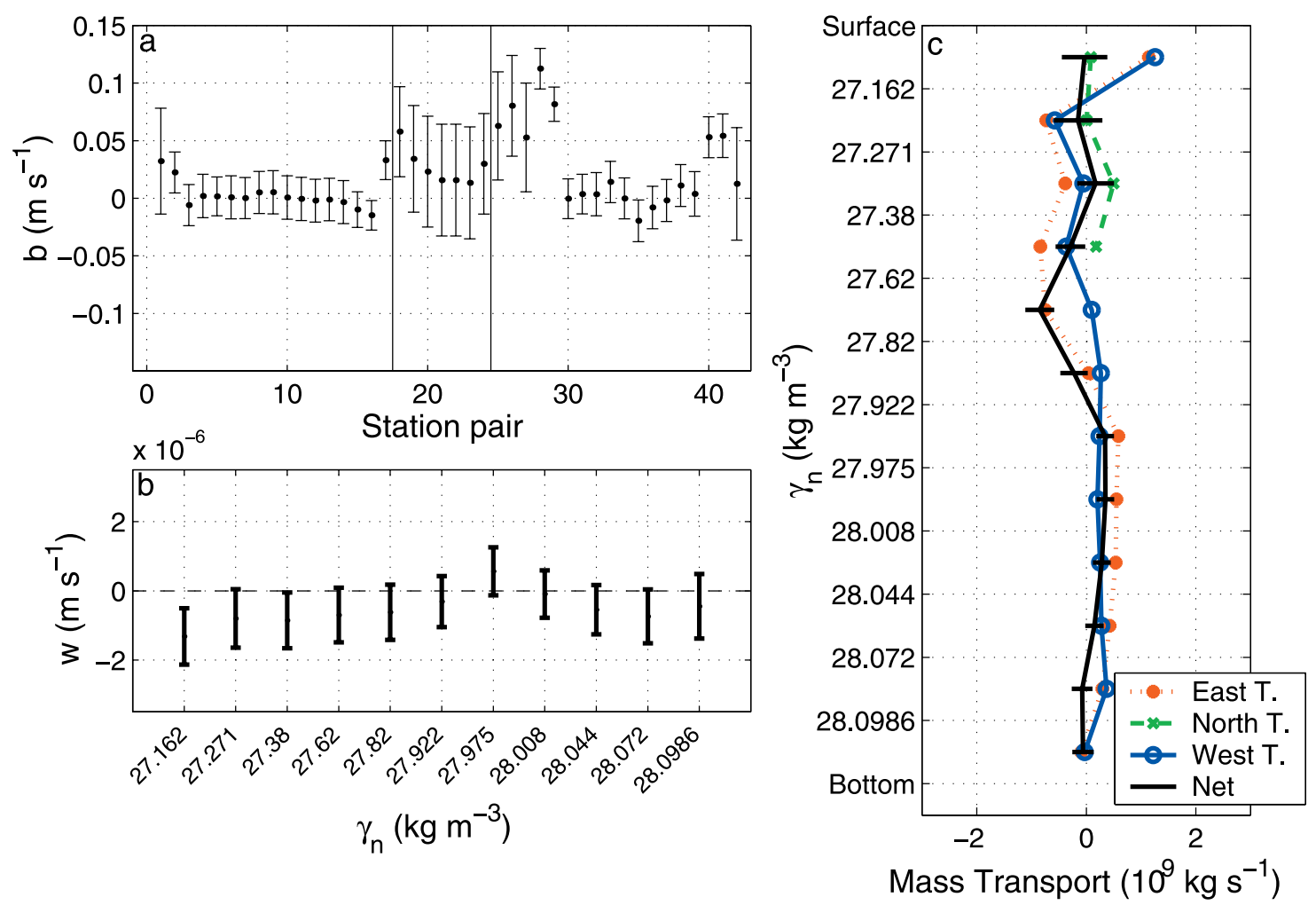

Figure 6. (a) Velocity values for each station pair, (b) dianeutral velocities between layers determined by inverse calculations together with the error bars, and (c) the integrated mass transport as a function of density layer, calculated with the inverse model for the west (open circles, thin solid line), north (crosses, dashed line), and east (solid circles, dotted line) section together with their sum (thick solid line). For each section, positive/negative sign means northward/southward or eastward/westward flow. The sign of the net transport is taken positive/negative for divergence/convergence flow out/in the box.

range of depths (surface to $200 \mathrm{~m}$ ) and for the same season with velocities up to $5 \mathrm{~cm} \mathrm{~s}^{-1}$. The northern transect, from station 18 to 25 , is quite shallow and shows a net northward transport of $+0.6 \pm 0.7 \mathrm{~Sv}$, that is not statistically significant. Finally, the eastern transect, from stations 25 to 43 , shows a null net transport due to the strong recirculation and high mesoscale activity. The net imbalance of our model for the surface layers is practically zero, $-0.1 \pm 0.1 \mathrm{~Sv}$.

[29] Figure 8 shows a velocity modal comparison between the calculated surface geostrophic velocities and those estimated from surface altimetry. These velocities fields have similar spatial pattern, and the velocity surface magnitudes agree well, in the western and northern transect. However, geostrophic velocities in the eastern transect are substantially different from the altimetry-derived velocities. The reason for this disagreement is likely due to the time lag between the hydrographic transect and the satellite pass and the fact that the time variability over the Biscay Abyssal Plain is large compared to the mean circulation [Friocourt et al., 2007]. The measurements are not coincident in time and the numerous mesoscale features, as seen in satellite altimetry, yield the different patterns in the velocity field seen in Figure 8.

[30] The Ekman transport adjustment $\left(\Delta T_{E k}\right)$ as a result of the inverse box model is $-0.01 \pm 0.01 \mathrm{~Sv}, 0.03 \pm 0.12 \mathrm{~Sv}$ and $0.25 \pm 0.20 \mathrm{~Sv}$ for the western, northern and eastern sections, respectively. The final Ekman transport for each section is $-0.1 \pm 0.01 \mathrm{~Sv}, 0.28 \pm 0.12 \mathrm{~Sv}$ and $0.69 \pm 0.20 \mathrm{~Sv}$ that has been added to the shallowest layer. The freshwater flux computed as part of the solution of the inverse model is indistinguishable from zero $(0.008 \pm 0.035 \mathrm{~Sv})$, and less than that from the da Silva et al. [1994] climatology and the

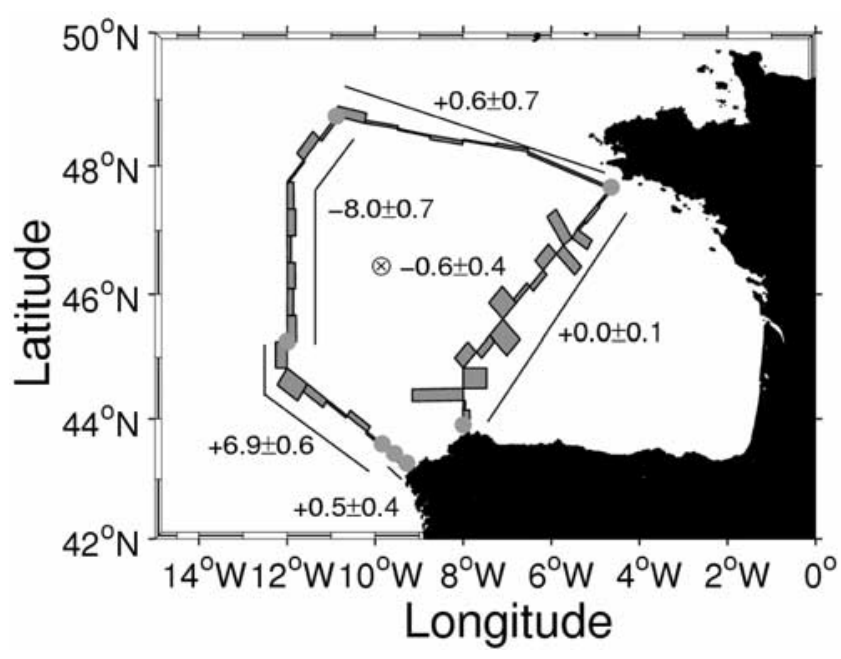

Figure 7. Mass transports for groups of station pairs with their standard deviation in (Sv). Negative Ekman pumping is shown as a circles cross in the center of the Box A. 




Figure 8. Velocity comparison between the model-derived velocities (red arrows) and those estimated from surface altimetry (green arrows) projected onto the normal axis between the pair stations. Blue arrows are the geostrophical surface velocity estimated by the Jason-1 altimetry for a whole basin. Two different scales were used in order to emphasize the normal projection (red and green arrows).

freshwater runoff from Koutsikopoulos and Le Cann [1996] that gives a net precipitation of $-0.07 \mathrm{~Sv}$ in our region.

[31] The intermediate waters, as described in section 3, follow the same surface pattern as the thermocline waters as a subsurface eastern boundary current. The net imbalance of our model for these layers is $-1.4 \pm 0.4 \mathrm{~Sv}$. Intermediate waters flow eastward into the box between stations 17 and 9 with a net transport of $-7.9 \pm 1.0 \mathrm{~Sv}$ and flow southwestward out of the box between stations 8 and 1 with a net transport of $+8.0 \pm 1.0 \mathrm{~Sv}$. The eastern transect shows, as at the surface layers, a recirculation flow of $-1.5 \pm 0.5 \mathrm{~Sv}$. Dianeutral velocities are not significantly different from zero but, as at the surface layers, these velocities are negative, typical of anticyclonic patterns.

[32] Finally, our results show that deep water also flows into the box between stations 17 and 10 with a net transport of $-3.6 \pm 2.0 \mathrm{~Sv}$, and flow out of the box between stations 9 and 4 with a net transport of $2.3 \pm 2.0 \mathrm{~Sv}$. The eastern transect of Box A shows a net transport of $-2.3 \pm 0.3 \mathrm{~Sv}$. The net imbalance just for the deeper layers is $+1.0 \pm 0.4 \mathrm{~Sv}$.

[33] Acknowledgments. MIDAS-4 project (ESP2005-06823-C0505), supported by the Science and Education Department of Spain for supporting the SMOS mission (monitoring the surface salinity of the oceans), for financing the contract of the main author. Project VACLAN (REM2003-08193-C03-00/MAR) was carried out from 2003 to 2005 and supported by the CICYT and the Instituto Español de Oceanografía (Spanish Institute of Oceanography) [IEO], for financing the cruise. The authors would like to thank the officers and crew of the R/V Thalassa for their invaluable contributions. We thank Evan Mason and Jaime Palter for their help with the English language and two anonymous reviewers for their helpful comments on the manuscript.

\section{References}

Ambar, I., and M. Howe (1979), Observations of the Mediterranean outflow-I: Mixing in the Mediterranean outflow, Deep Sea Res., Ser. A, 26, 535,535 .

Arhan, M. (1990), The North Atlantic Current and Subarctic Intermediate Water, J. Mar. Res., 48, 109-144.

Botas, J., E. Fernández, A. Bode, and R. Anadón (1989), Water masses off the Central Cantabrian Coast, Sci. Mar., 53, 755-761.

Chantry, P. (1995), Contribution à la connaissance de l'hydrologie et de la dynamique dans le Golfe de Gascogne à partir des données de la campagne GASTOM90, Ph.D. thesis, l’Université Pierre et Marie Curie, Paris.

da Silva, A., A. Young, and S. Levitus (1994), Atlas of Surface Marine Data 1994, vol. 1, Algorithms and Procedures, NOAA Atlas NESDIS 6, NOAA, Silver Spring, Md.

Durrieu de Madron, X., P. Castaing, F. Nyffeler, and T. Courp (1999), Slope transport of suspended particulate matter on the Aquitanian margin of the Bay of Biscay, Deep Sea Res., Part II, 46, 2003-2027.

Fraile-Nuez, E. (2005), Determinación de la variabilidad estacional del transporte de masa, calor y agua dulce en la cuenca este del Giro Subtropical del Atlántico Norte mediante el uso de perfiladores lagrangianos, Ph.D. thesis, Univ. de Las Palmas de Gran Canaria, Las Palmas de Gran Canaria, Spain.

Friocourt, Y., B. Levier, S. Speich, B. Blanke, and S. Drijfhout (2007), A regional numerical ocean model of the circulation in the Bay of Biscay, J. Geophys. Res., 112, C09008, doi:10.1029/2006JC003935.

Frouin, R., A. Fiúza, I. Ambar, and T. Boyd (1990), Observations of a poleward surface current off the coasts of Portugal and Spain during winter, J. Geophys. Res., 95(C1), 679-691. 
Ganachaud, A. (1999), Large scale oceanic circulation and fluxes of freshwater, heat, nutrients and oxygen, Ph.D. thesis, Mass. Inst. of Technol./ Woods Hole Oceanogr. Inst. Jt. Program, Cambridge.

Ganachaud, A. (2003a), Large-scale mass transports, water mass formation, and diffusivities estimated from World Ocean Circulation Experiment (WOCE) hydrographic data, J. Geophys. Res., 108(C7), 3213, doi:10.1029/2002JC001565.

Ganachaud, A. (2003b), Error budget of inverse box model: The North Atlantic, J. Atmos. Oceanic Technol., 20, 1641-1655.

Ganachaud, A., C. Wunsch, J. Marotzke, and J. Toole (2000), The meriodional overturning and large-scale circulation in the Indian Ocean, J. Geophys. Res., 105(C11), 26,117-26,134

Garrett, C. (1991), Marginal mixing theories, Atmos. Ocean, 29, 313-339.

González-Pola, C., A. Lavín, and M. Vargas-Yáñez (2005), Intense warming and salinity modification of intermediate water masses in the southeastern corner of the Bay of Biscay for the period 1992-2003, J. Geophys. Res., 110, C05020, doi:10.1029/2004JC002367.

Haynes, R., and E. Barton (1990), A poleward flow along the Atlantic coast of the Iberian Peninsula, J. Geophys. Res., 95(C7), 11,425-11,441.

Hernández-Guerra, A., E. Fraile-Nuez, F. López-Laatzen, A. Martínez, G. Parrilla, and P. Vélez-Belchí (2005), Canary Current and North Equatorial Current from an inverse box model, J. Geophys. Res., 110, C12019, doi:10.1029/2005JC003032.

Huthnance, J., H. van Aken, M. White, E. Barton, B. Le Cann, E. Ferreira Coelho, E. Alvarez Fanjul, P. Miller, and J. Vitorino (2002), Ocean margin exchange-water flux estimates, J. Mar. Syst., 32, 107-137.

Isemer, H., and L. Hasse (1987), The Bunker Climate Atlas of the North Atlantic Ocean, vol. 1, 252 pp., Springer, New York.

Jackett, D., and T. McDougall (1997), A neutral density variable for the world's ocean, J. Phys. Oceanogr., 27, 237-263.

Joyce, T., A. Hernández-Guerra, and W. Smethie Jr. (2001), Zonal circulation in the NW Atlantic and Caribbean from a meridional WOCE hydrographic section at $66^{\circ} \mathrm{W}, J$. Geophys. Res., 106(C10), 22,09522,113 .

Koutsikopoulos, C., and B. Le Cann (1996), Physical processes and hydrological structures related to the Bay of Biscay anchovy, Sci. Mar., 60, 9-19.

Levitus, S., and T. Boyer (1994), World Ocean Atlas 1994, vol. 4, Temperature, NOAA Atlas NESDIS 4, NOAA, Silver Spring, Md.

Machín, F. (2004), Variabilidad espacio temporal de la Corriente de Canarias, del afloramiento costero al noroeste de África y de los intercambios atmósfera-océano de calor y agua dulce, Ph.D. thesis, Univ. de Las Palmas de Gran Canaria, Las Palmas de Gran Canaria, Spain.

Machín, F., A. Hernández-Guerra, and J. Pelegrí (2006), Mass fluxes in the Canary Basin, Prog. Oceanogr., 70, 416-447.

Mazé, J., M. Arhan, and H. Mercier (1997), Volume budget of the eastern boundary layer off the Iberian Peninsula, Deep Sea Res., Part I, 44, $1543-1574$

Paillet, J., and H. Mercier (1997), An inverse model of the eastern North Atlantic general circulation and thermocline ventilation, Deep Sea Res. Part I, 44, 1293-1328.

Peliz, A., T. Rosa, A. Santos, and J. Pissarra (2002), Fronts, jets, and counter-flows in the western Iberian upwelling system, J. Mar. Syst., 35, 61-77.

Pingree, R. (1993), Flow of surface waters to the west of the British Isles and in the Bay of Biscay, Deep Sea Res., Part II, 40, 369-388.
Pingree, R., and B. Le Cann (1992), Anticyclonic Eddy X91 in the Southern Bay of Biscay, May 1991 to February 1992, J. Geophys. Res., 97(C9), 14,353-14,367.

Pollard, R., and S. Pu (1985), Structure and circulation of the upper Atlantic Ocean northeast of the Azores, Prog. Oceanogr., 14, 443-462.

Puillat, I., P. Lazure, A. Jégou, L. Lampert, and P. Miller (2004), Hydrographical variability on the French continental shelf in the Bay of Biscay, during the 1990s, Cont. Shelf Res., 24, 1143-1163.

Reid, J. (1994), On the total geostrophic circulation of the North Atlantic Ocean: Flow patterns, tracers, and transports, Prog. Oceanogr., 33, 1-92.

Smith, W., and D. Sandwell (1997), Global sea floor topography from satellite altimetry and ship depth soundings, Science, 277, 1956-1962.

Swallow, J., W. Gould, and P. Saunders (1977), Evidence for a poleward eastern boundary current in the North Atlantic Ocean, CM 32, 21 pp., Int Counc. for the Explor. of the Sea, Copenhagen.

van Aken, H. (2000a), The hydrography of the mid-latitude Northeast Atlantic Ocean I: The deep water masses, Deep Sea Res., Part I, 47, $757-788$.

van Aken, H. (2000b), The hydrography of the mid-latitude Northeast Atlantic Ocean II: The intermediate water masses, Deep Sea Res., Part $I, 47,789-824$

van Aken, H. (2001), The hydrography of the mid-latitude Northeast Atlantic Ocean III. The subducted thermocline water mass, Deep Sea Res., Part I, 48, 237-267.

van Aken, H. (2002), Surface currents in the Bay of Biscay as observed with drifters between 1995 and 1999, Deep Sea Res., Part I, 49, 1071-1086.

van Aken, H., and G. Becker (1996), Hydrography and through-flow in the north-eastern North Atlantic Ocean: The NANSEN project, Prog. Oceanogr., 38, 297-346.

Vincent, A. (1973), Les variations de la situation thermique dans le Golfe de Gascogne en 1969 et 1979, Rev. Travaux Inst. Pêches Mar., 37(1), 5-18.

Vincent, A., and G. Kurc (1969), Hydrologie, variations saisonniéres de la situation thermique du Golfe de Gascogne en 1967, Rev. Travaux Inst. Pêches Mar., 33(1), 79-96.

Wunsch, C. (1977), Determining the general circulation of the oceans: A preliminary discussion, Science, 196, 871-875.

Wunsch, C. (1978), The North Atlantic general circulation west of $50^{\circ} \mathrm{W}$ determined by inverse methods, Rev. Geophys., 16, 583-620.

Wunsch, C. (1996), The Ocean Circulation Inverse Problem, 442 pp., Cambridge Univ. Press, New York.

E. Fraile-Nuez, Instituto Español de Oceanografía, Centro Oceanográfico de Canarias, E-38005 Santa Cruz de Tenerife, Spain. (eugenio.fraile@ ca.ieo.es)

A. Hernández-Guerra, Facultad de Ciencias del Mar, Universidad de Las Palmas de Gran Canaria, E-35017 Las Palmas, Spain. (ahernandez@dfis. ulpgc.es)

A. Lavín, Instituto Español de Oceanografía, Centro Oceanográfico de Santander, E-39080 Santander, Spain. (alicia.lavin@st.ieo.es)

F. Plaza, Instituto Español de Oceanografía, Centro Oceanográfico de Murcia, E-30740 San Pedro del Pinatar, Spain. (francisco.plaza@mu.ieo.es)

M. Vargas-Yáñez, Instituto Español de Oceanografía, Centro Oceanográfico de Málaga, E-29640 Fuengirola, Spain. (manolo.vargas@ma.ieo.es) 